\title{
Does Spray Mango Kernel (Mangifera indica Linn.) Prolong the Shelf Life of Beef Sausages?
}

\author{
Aly R. Abdel-Moemin ${ }^{1}$ \\ ${ }^{1}$ Nutrition and Food Science, Faculty of Home Economics, Helwan University, Egypt \\ Correspondence: Aly R. Abdel-Moemin, Nutrition and Food Science, Faculty of Home Economics, Helwan \\ University, Egypt. Tel: 20-233-908-130. E-mail: dralymoemin@yahoo.co.uk
}

Received: February 18, 2015

Accepted: March 18, 2015 Online Published: March 24, 2015

doi:10.5539/jfr.v4n3p118

URL: http://dx.doi.org/10.5539/jfr.v4n3p118

\begin{abstract}
The study was aimed to look at the effect of different forms of mango kernels (MK) on the shelf life of refrigerated beef sausages over 12 days of cold storage. The (MK) was chemically and microbiologically analyzed. Beef sausages were treated with MK in 3 states, as dry ground (1.5\%), an extract (1.5\%) and spray MK extract (1.5\%) over minced beef of sausages. Two controls were used; BHT $0.02 \%$ and no additives. A series of analyses were performed after treatments; thiobarbituric acid reactive substances (TBARS), analysis of color, myoglobin and odor. The results indicated that different forms of MK added to the beef sausages had different effects on its shelf life. Furthermore, the sprayed MK extract has significantly $(\mathrm{P} \leq 0.05)$ lowered metmyoglobin $(\mathrm{MMb})$ and TBARS and increased oxymyoglobin $\left(\mathrm{MbO}_{2}\right)$, odor score and $\mathrm{a}^{*}$ (redness) than other forms. The potential effects of the sprayed MK may be due to a cloud of droplets cover the large surfaces of minced beef sausages with efficient extracted antioxidants. MK is source of flavonoids $142 \mathrm{mg} / \mathrm{g} \mathrm{F}$.W. GAE. The spraying of MK at $1.5 \%$ showed an improvement of $E$. coli from minced beef and beef sausages that were less than $10 \mathrm{cfu} \mathrm{g}^{-1}$ Also the concentrations of yeasts and moulds were not detected at day 12 of storage. Hierarchically, sprayed MK extract gave best results than ground MK or MK extract form which shows effective inhibitor of lipid oxidation and microbial growth of beef sausages.
\end{abstract}

Keywords: sprayed mango kernels, beef sausage, lipid oxidation, myoglobin, shelf life, antioxidative and anti-microbiological

\section{Introduction}

Fruits wastes make a large component of solid waste residue from agro-fruit processing industries that could increase environmental pollution due to its rapid decay. It has been reported that $45 \%$ of wastes are from mangoes, compared to $50 \%$ from citrus fruits and $10 \%$ from apples (Rao, 2006). Fruit peels and seeds are the most enriched part of fruits as they act as storage sites for nutrients required by the young plants. They have also been suggested to have antioxidant properties. Fiber-rich by-products may be incorporated into food products as inexpensive, non-caloric bulking agents for partial replacement of flour, fat or sugar, as enhancers of water and oil retention (Soong \& Barlow, 2004).

Mango (Mangifera indica Linn.) is considered as one of the most summer favorite fruits in Egypt. During processing of mango, by-products such as peel and seed kernel are produced. Seed kernels may take up about $17-22 \%$ of the fruit. Mango seed is a single flat rectangular seed that can be fibrous or hairy on the surface, depending on the cultivar. Inside the seed coat $1-2 \mathrm{~mm}$ thick is a thin lining covering a single embryo, $4-7 \mathrm{~cm}$ long, 3- $4 \mathrm{~cm}$ wide, and $1 \mathrm{~cm}$ thick.

The MK has shown to be a good source of flavonoids, phytosterols such as campesterol, sitosterol and vitamin E as well. (Kittiphoom, 2012).

Meat products such as beef sausages are highly perishable and deteriorate rapidly causing potentially dangerous health risks through microbial growth and chemical changes. During storage in the presence of oxygen the oxidation of lipids takes place with production of free radicals as consequence of the metabolic changes in a meat biological system (Lee et al., 1998; Olsen et al., 2005). Lipid oxidation products contribute to the undesirable changes such as oxidation of oxymyoglobin to metmyoglobin which results in dark brown meat color (Renerre \& Labas, 1987; Lee et al., 1998). 
A small number of studies had investigated the possibility of MK to extend the shelf life of meat products. However, we have not a conclusion so far about the best form of MK to prolong the shelf life of beef sausages. Gadallah and Abdel Fatah (2011) tested the antibacterial effect of MK in a powder and extracted form with methanol at different levels 1.0, 2.0, 3.0 to treat minced beef over 15 days of cold storage. While Hung (2012) studied the antioxidative effect of ground MK $(1 \% \mathrm{w} / \mathrm{w})$ on the shelf life of pork sausages and pork patties over 10 days of cold storage. Also Pereira et al (2011) tested the inclusion of mango seed extract (MSE) at different levels $0.1 \%$ and $0.2 \%$ in Bologna-type mortadella preparations and found the $0.2 \%$ promotes higher $\mathrm{pH}$ values after 14 and 21 days of storage at $2{ }^{\circ} \mathrm{C}$. However, the researcher concluded that mango seed extract (MSE) can be used in 0.1 or $0.2 \%$ levels in Bologna-type mortadella with similar or better antioxidant effects than those of BHT $0.01 \%$.

The objective of the present study was to optimize the best form of MK that prolongs the shelf life of beef sausage over 12 days of cold storage. For first time we investigated the effect of spraying MK extract on the shelf life of beef sausages at $1.5 \%$ level.

\section{Materials and Methods}

\subsection{Materials}

Mango seed kernels were collected from local juice shops, Cairo suburb, Egypt after mango flesh processing from (Zebda) variety during the summer season of 2014. The average weight of mangoes $375 \mathrm{~g}$, they can be described according to Kader (2008) as relatively strong, firm, green to yellow and less full cheek. Beef legs were purchased from Cairo butcher shop.

Chemicals such as trichloroacetic acid (TCA), thiobarbituric acid (TBA), 1,1,3,3-tetramethoxypropane (TMP), ethanol, sulphuric acid, hydrochloric acid, ethyl acetate, Whatman 1 filter were obtained from Sigma, Egypt. Folin-Ciocalteu's phenol reagent, sodium carbonate $\left(\mathrm{Na}_{2} \mathrm{CO}_{3}\right)$ and gallic acid were purchased from Sigma-Aldrich (St. Louis, MO). The rest of chemicals were purchased from El Gomhoria Chemical Company, Cairo, Egypt.

\subsection{Proximate Analysis of $M K$}

Three samples $(5 \mathrm{~g})$ from each MK were examined for lipid, protein, ash and carbohydrate contents according to the official methods AOAC (2000). Moisture and dry matter were determined in MK by using "Infrared Moisture Determination Balance (FD-610-Japan) with a $5 \mathrm{~g}$ sample at $80{ }^{\circ} \mathrm{C}$ for $60 \mathrm{~min}$. Carbohydrates were calculated by difference. The amount of total flavonoids content was determined by using Folin-Ciocalteu reagent according to Singleton and Rossi, (1965) with little modification according to Abdel-Moemin (2014) (CT-2200 Spectrophotometer, E-Chrom Tech, Taiwan).

\subsection{Extraction of $M K$}

The freeze-dried powder of MK (Snijders Scientific-tilburg, Holland, capacity $3 \mathrm{~kg}$ Ice) was extracted to ethanolic solvent according to Vega-Vega et al. (2013). Ethanolic extracts of MK was carried out by weighing $(10 \mathrm{~g})$ of MK and placed in E-Flask with $100 \mathrm{~mL}$ of ethanol: water (70:30). The sample was left to infuse in a dark room for 10 days at $25-30{ }^{\circ} \mathrm{C}$. The extract was then filtered and the solvent removed by using a rotary evaporator at reduced pressure and temperature of $45^{\circ} \mathrm{C}$. The aqueous fraction was freeze-dried, forming the dry extract, which was subject to alkaline hydrolysis $(10 \mathrm{~mL}$ of $\mathrm{NaOH} 4 \mathrm{M})$ for $4 \mathrm{~h}$ in darkness. Therefore, an acid hydrolysis was conducted with $\mathrm{HCl} 4 \mathrm{M}$ taken every sample to $\mathrm{pH} 2$. The hydrolyzed extract was subject to liquid-liquid separation by 2 washes with $20 \mathrm{~mL}$ of ethyl acetate (Oboh \& Rocha, 2007). The ethyl acetate phase was used and evaporated; the obtained extract was re-suspended in deionised water to a concentration of $25 \mathrm{mg}$ of extract per $\mathrm{mL}$.

\subsection{Preparation of Beef Sausages}

Three samples of beef legs were purchased after 24 hours post-slaughter beef Caracas from local butchers Cairo, Egypt. Three forms of MK were treated the minced beef suasges; ground MK at $1.5 \%$, extract MK $1.5 \%$ and spray MK at $1.5 \%$. For example, ground sample of MK was mixed with minced beef sausage in a food processor for 3 minutes to prepare the beef sausages. Furthermore, the spray MK extract was sprayed over minced beef sausage through household sprayer. Controls (without additives) and BHT were also blended similarly to the above. Portions used to make the beef suasges in this study were in Table 1. 
Table 1. Preparation of beef sausages

\begin{tabular}{llllll}
\hline \multirow{2}{*}{ Ingredients } & \multicolumn{5}{c}{ Sausage recipes } \\
\cline { 2 - 6 } & Control & BHT & Extract & Spray & Ground \\
\hline Minced beef $(\mathrm{g})$ & 600 & 600 & 600 & 600 & 600 \\
MK $(\%)$ & - & - & Extract & Spray & Ground \\
*BHT $(\%)$ & - & 0.02 & -- & - & - \\
Salt $(\mathrm{g})$ & 3 & 3 & 3 & 3 & 3 \\
\hline Pepper $(\mathrm{g})$ & 2.4 & 2.4 & 2.4 & 2.4 & 2.4 \\
\hline
\end{tabular}

Control: Standard sausage recipe made from minced beef with no antioxidants, BHT: a sausage recipe made from minced beef at $0.02 \%$ BHT(control II), Extract: a sausage recipe made from minced beef and blended with MK extract at $1.5 \%$, Spray: a sausage recipe made from minced beef and sprayed with mango kernels extract at $1.5 \%$. Ground: a sausage recipe made from minced beef with ground mango kernels at $1.5 \%$ *Butylated hydroxytoluene with a concentration of $0.02 \%$.

Each recipe was then extruded into $10 \mathrm{~cm}$ natural sheep intestinal casings and air dried at $10{ }^{\circ} \mathrm{C}$ for 6 hours. The beef sausages ( $n=9$ per treatment) were placed in polystyrene trays which were covered with polyvinyl chloride film and then stored at $4{ }^{\circ} \mathrm{C}$ for $1,2,4,6,8,10$ and 12 days. Sampling was performed every 2 days to assess the effect of the extract applied on beef sausages.

\subsection{Proximate Analysis of Minced Beef and Beef Sausages}

Moisture and dry matter were determined by using (Infrared Moisture Determination Balance FD-610-Japan). Crude fat content was determined by using Soxhlet extraction (AOAC 976.21). Crude protein was measured by determining nitrogen using the Kjeldahl method (AOAC 981.10). Nitrogen was converted to crude protein content by multiplying with the factor 6.25 .

\subsection{Thiobarbituric Acid Reactive Substances (TBARS)}

Thiobarbituric acid reactive substances (TBARS) in minced and beef sausages were modified slightly from Maraschiello et al. (1999). Briefly, $0.5 \mathrm{~g}$ of meat was added to $10 \mathrm{~mL}$ of deionised water and homogenized (1 min). $2.5 \mathrm{~mL}$ of $25 \%$ TCA were added (to precipitate the protein), samples were stored for $10 \mathrm{~min}$ at $4{ }^{\circ} \mathrm{C}$ and centrifuged $\left(8 \mathrm{~min}, 3000 \mathrm{rpm}\right.$, at $\left.4{ }^{\circ} \mathrm{C}\right)$. An aliquot of $3.5 \mathrm{~mL}$ of the supernatant was added to $1.5 \mathrm{~mL}$ of $0.6 \%$ TBA and incubated in water bath for $30 \mathrm{~min}$ at $90^{\circ} \mathrm{C}$. The intensity of the developed color was measured at 539 $\mathrm{nm}$ UV-visible spectrophotometer CT-2200 Spectrophotometer, E-Chrom Tech, Taiwan) against a blank consisting of $2.5 \mathrm{~mL}$ of deionised water, $1 \mathrm{~mL} 25 \%$ aqueous TCA, and $1.5 \mathrm{~mL} 0.6 \%$ TBA.

\subsection{Determination of Myoglobin}

Deoxymyoglobin $(\mathrm{Mb})$, oxymyoglobin $\left(\mathrm{MbO}_{2}\right)$ and metmyoglobin $(\mathrm{MMb})$ in minced beef and sausages were determined according to the procedure of Krzywicki (1982). The absorbance of each supernatant was read at 565, 545 and $525 \mathrm{~nm}$ in a UV-visible spectrophotometer CT-2200 Spectrophotometer, E-Chrom Tech, Taiwan. Percentages of $\mathrm{Mb}, \mathrm{MbO}_{2}$ and $\mathrm{MMb}$ in the pigment extracts were calculated.

\subsection{Determination of Suasges Odor}

Odor acceptability of beef sausage $(\mathrm{n}=3)$ for a period of 6 subplots $(2,4,6,8,10,12)$ was assessed by 9 panelists at room temperature $\left(30^{\circ} \mathrm{C}\right)$, the cut of point for acceptable odor sausage was 2.5 marks by using a 5 -point hedonic scale where 1 =very unpleasant, 2 = moderately unpleasant, $3=$ moderately pleasant, $4=$ pleasant and 5 $=$ very pleasant (Das et al., 2011).

\subsection{Determination of Sausage Color}

The beef sausages samples were taken out of the refrigerator and placed on the table for 5 minutes at room temperature $\left(30^{\circ} \mathrm{C}\right)$ before color measurement. Color measurements were made on the surface of raw beef sausages with Minolta Chroma Meter CR-310 colorimeter (Minolta Corp., Ramsey, NJ).The colorimeter was calibrated according to the manufactures instructions.

\subsection{Microbiology of Beef Sausages}

Microbiological profile of MK, fresh minced beef and stored sprayed beef sausages with MK were done on the day 12. The examination included TVC, E. coli, staphylococci, coliforms yeasts, moulds and Salmonella for 
minced beef and refrigerated stored beef sausages. The MK samples were also analyzed for TVC, E. coli, Bacillus cereus, yeasts and moulds.

\subsection{Statistics}

Means and standard deviations \pm SD were calculated. One Way Analysis of Variance (ANOVA) was conducted. The critical values for the Tukey HSD Test were used in significance at $(\mathrm{P} \leq 0.05)$ Innersoft stats $\mathrm{v} 0.8$, version 0.8 .00 , copyright 2013 Innersoft.

\section{Results}

The percentage average of Zebda mangoes portions were of 78, 8.5,11 and 2.5\% for flesh, peel, kernel and kernel crust (the hard layer that cover the seed) respectively. The average moisture content was 85.4, 74.2, 38.42 and $12 \%$ for mango flesh, mango peel, kernels and kernel crust respectively.

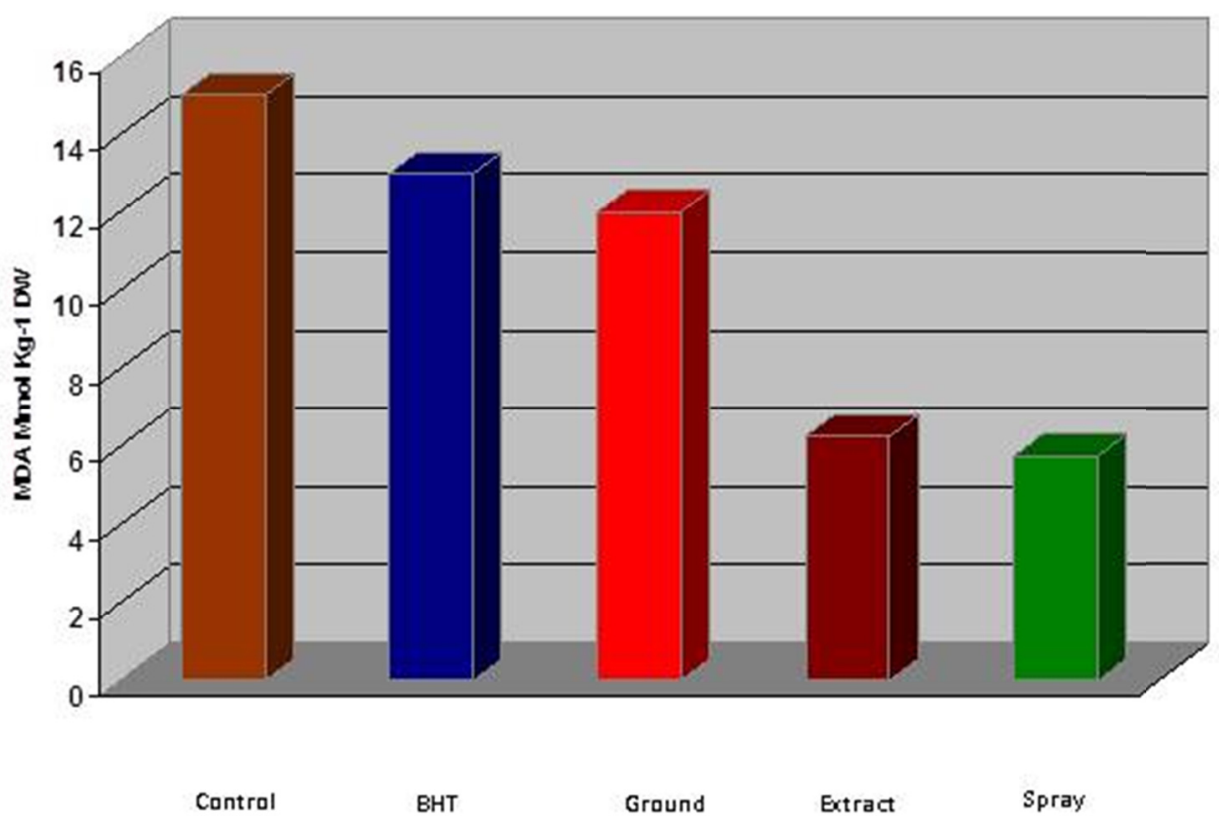

Figure 1. TBARS (MDA) values $\left(\mu \mathrm{mol} \mathrm{Kg}^{-1} \mathrm{DW}\right)$ in sausages treated with the 3 forms of MK at $\left({ }^{\circ} \mathrm{C}\right)$ at day 12

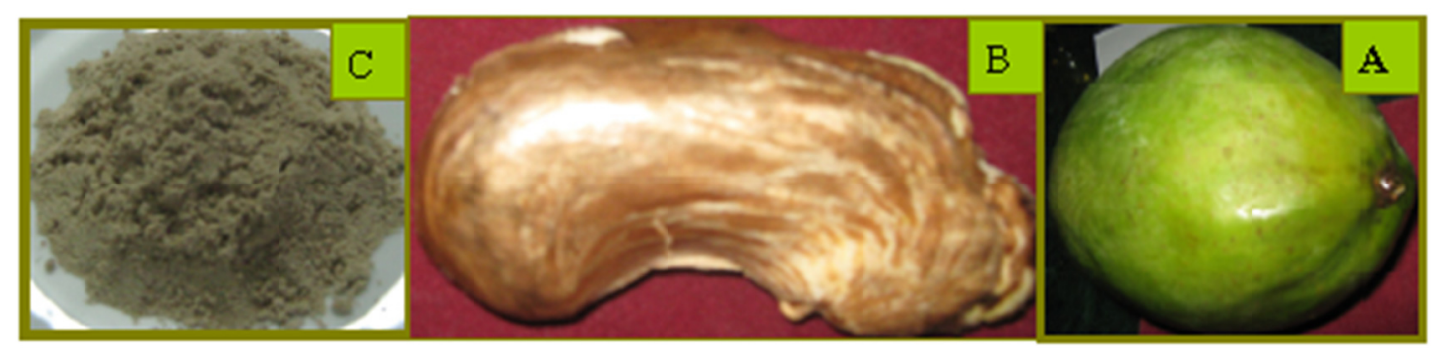

Figure 2. A: Mango fruit (Zebda) ( Mangifera indica Linn.), B: Mango Kernel, C: ground mango kernels

\subsection{Proximate Analysis of Mango Kernels}

The results in Table 2 indicate to the average chemical composition of MK, for example, fat content constitutes $6.94 \%$. The MK constituted about 1.93 crude protein (Nx6.25), (1.61\%) crude ash, (47.19\%) crude carbohydrate, and $(258.75 \mathrm{Kcals}-1035 \mathrm{KJ})$ gross energy. The total phenolic content of dried mango kernel was $142 \mathrm{mg} / \mathrm{g}$ F.W.GAE 
Table 2. Proximate analysis of $\mathrm{MK} \%$

\begin{tabular}{llllllll}
\hline $\begin{array}{l}\text { Moisture } \\
\%\end{array}$ & Crude & Fats & Crude & Ash & Carbohydrates & Energy & Total phenolics mg/g \\
KJ & F.W.GAE \\
\hline $38.42 \pm 0.4$ & $1.93 \pm 0.6$ & $6.94 \pm 0.8$ & $3.91 \pm 1.5$ & $1.61 \pm 0.2$ & $47.19 \pm 0.8$ & 1035 & $142 \pm 1.5$ \\
\hline
\end{tabular}

\subsection{Microbiological Profile of Mango Kernels}

The microbiological profile of MK was safe which recorded $900 \mathrm{cfu}^{-1}$ for TVC and less than for the following; $50 \mathrm{cfu} \mathrm{g}^{-1}$ for yeasts and moulds, $10 \mathrm{cfu} \mathrm{g}^{-1}$ for Bacillus and $5 \mathrm{Cfu} \mathrm{g}^{-1}$ for E. coli.

\subsubsection{Proximate Analysis of Fresh Minced Beef}

The proximate composition of fresh minced beef for moisture, crude protein, fat, ash and carbohydrates were $60.2 \pm 0.36,17.9 \pm 3.2,18.2 \pm 2.7,2.48 \pm$ and $1.22 \pm 3.6 \% \mathrm{FW}$ respectively.

\subsection{Odor of Sausages}

The sausages, regardless of their components, showed a decrease in their odor scores over the 12 days of cold storage. The beef sausages without antioxidants (control I) decreased the odor (unpleasant odor) from 5 to 0 after 12 days of storage. Furthermore, had an undesirable score $(<2.5)$ and unpleasant odor after 4 days of storage. Nevertheless, the odor score of sausages with MK spray, extract and ground had acceptable score ( $\geq 2.5)$ for up to 8 days of storage whilst those with sprayed with MK had $(\geq 3)$ for up to 10 days. However, added BHT had an acceptable margin score (2.5).

Table 3. Myoglobin pigments (\%) in the beef sausages during storage period $\left(4^{\circ} \mathrm{C}\right)$

\begin{tabular}{|c|c|c|c|c|c|}
\hline \multirow{2}{*}{$\begin{array}{l}\text { Days } \\
\text { Days }\end{array}$} & \multicolumn{5}{|c|}{$* * \mathbf{M b} \%$} \\
\hline & Control & BHT & Extract & Spray & Ground \\
\hline $1 *$ & $30 \pm 0.2$ & $30 \pm 1.3$ & $42 \pm 2.2$ & $45 \pm 1.2$ & $32 \pm 3.1$ \\
\hline 2 & $32 \pm 2.3$ & $35 \pm 1.2$ & $37 \pm 0.3$ & $35 \pm 0.4$ & $35 \pm 1.5$ \\
\hline 4 & $45 \pm 1.1$ & $37 \pm 0.5$ & $35 \pm 1.2$ & $32 \pm 0.2$ & $36 \pm 1.8$ \\
\hline 6 & $38 \pm 1.3$ & $37 \pm 2.0$ & $33 \pm 1.4$ & $32 \pm 1.8$ & $37 \pm 2.2$ \\
\hline 8 & $42 \pm 2.1$ & $38 \pm 2.2$ & $31 \pm 0.9$ & $31 \pm 1.1$ & $37 \pm 2.4$ \\
\hline 10 & $53 \pm 0.1$ & $37 \pm 0.7$ & $34 \pm 0.2$ & $31 \pm 1.3$ & $40 \pm 2.2$ \\
\hline 12 & $55 \pm 1.4$ & $40 \pm 0.2$ & $34 \pm 1.6$ & $32 \pm 2.2$ & $41 \pm 3.2$ \\
\hline \multirow[t]{2}{*}{ Days } & \multicolumn{5}{|c|}{$\mathrm{MbO}_{2} \%$} \\
\hline & Control & BHT & Extract & Spray & Ground \\
\hline $1 *$ & $29 \pm 1.2^{\mathrm{b}}$ & $44 \pm 0.8^{\mathrm{a}}$ & $22 \pm 1.6^{\mathrm{d}}$ & $25 \pm 0.6^{\mathrm{c}}$ & $31 \pm 1.2^{\mathrm{ab}}$ \\
\hline 2 & $30 \pm 2.0^{\mathrm{ab}}$ & $37 \pm 3.1^{\mathrm{a}}$ & $23 \pm 1.2^{\mathrm{d}}$ & $30 \pm 2.3^{\mathrm{ab}}$ & $29 \pm 1.7^{\mathrm{ab}}$ \\
\hline 4 & $22 \pm 0.7^{\mathrm{ab}}$ & $35 \pm 2.2^{\mathrm{a}}$ & $25 \pm 3.0^{c}$ & $35 \pm 1.2^{\mathrm{a}}$ & $28 \pm 0.2^{\mathrm{b}}$ \\
\hline 6 & $17 \pm 1.4^{\mathrm{ab}}$ & $33 \pm 1.2^{\mathrm{a}}$ & $28 \pm 2.4^{\mathrm{b}}$ & $34 \pm 2.5^{\mathrm{a}}$ & $27 \pm 2.4^{\mathrm{b}}$ \\
\hline 8 & $15 \pm 0.2^{\mathrm{d}}$ & $32 \pm 1.5^{\mathrm{b}}$ & $30 \pm 0.9^{\mathrm{ab}}$ & $35 \pm 1.8^{\mathrm{a}}$ & $27 \pm 2.6^{\mathrm{c}}$ \\
\hline 10 & $14 \pm 2.2^{c}$ & $30 \pm 0.8^{\mathrm{b}}$ & $31 \pm 1.2^{\mathrm{b}}$ & $37 \pm 2.6^{\mathrm{a}}$ & $26 \pm 0.6^{\mathrm{ab}}$ \\
\hline 12 & $11 \pm 1.4^{\mathrm{c}}$ & $27 \pm 1.3^{\mathrm{ab}}$ & $34 \pm 0.2^{b}$ & $37 \pm 3.2^{\mathrm{a}}$ & $26 \pm 2.2^{\mathrm{ab}}$ \\
\hline \multirow[t]{2}{*}{ Days } & \multicolumn{5}{|c|}{ МMb \% } \\
\hline & Control & BHT & Extract & & Ground \\
\hline $1 *$ & $23 \pm 0.3^{\mathrm{b}}$ & $13 \pm 1.9^{c}$ & $17 \pm 0.1^{\mathrm{ab}}$ & $14 \pm 1.6^{\mathrm{c}}$ & $24 \pm 2.2^{\mathrm{a}}$ \\
\hline 2 & $27 \pm 1.8^{\mathrm{a}}$ & $15 \pm 2.2^{\mathrm{d}}$ & $19 \pm 1.3^{\mathrm{ab}}$ & $16 \pm 1.2^{c}$ & $23 \pm 0.8^{\mathrm{b}}$ \\
\hline 4 & $22.5 \pm 1.1^{\mathrm{b}}$ & $22 \pm 1.6^{b}$ & $14 \pm 2.4^{c}$ & $16 \pm 0.9^{\mathrm{ab}}$ & $25 \pm 1.5^{\mathrm{a}}$ \\
\hline 6 & $33.5 \pm 3.0^{\mathrm{a}}$ & $34 \pm 0.7^{\mathrm{a}}$ & $16 \pm 1.2^{\mathrm{c}}$ & $18 \pm 2.0^{\mathrm{ab}}$ & $28 \pm 1.2^{\mathrm{b}}$ \\
\hline 8 & $39 \pm 1.4^{\mathrm{a}}$ & $32 \pm 1.2^{\mathrm{b}}$ & $14 \pm 3.1^{\mathrm{ab}}$ & $12 \pm 1.4^{\mathrm{c}}$ & $33 \pm 0.7^{\mathrm{b}}$ \\
\hline 10 & $37 \pm 0.7^{\mathrm{a}}$ & $31 \pm 0.2^{\mathrm{b}}$ & $18 \pm 0.6^{\mathrm{ab}}$ & $12 \pm 1.1^{\mathrm{c}}$ & $37 \pm 1.6^{\mathrm{a}}$ \\
\hline 12 & $40 \pm 0.9^{\mathrm{a}}$ & $33 \pm 1.5^{\mathrm{ab}}$ & $20 \pm 1.2^{\mathrm{c}}$ & $14 \pm 2.4^{\mathrm{d}}$ & $37 \pm 3.0^{D}$ \\
\hline
\end{tabular}


Control: Standard sausage recipe made from minced beef with no antioxidants, BHT: a sausage recipe made from minced beef at $0.02 \%$ BHT. Extract: a sausage recipe made from minced beef and blended with MK extract at $1.5 \%$, Spray: a sausage recipe made from minced beef and sprayed with mango kernels extract at $1.5 \%$. Ground: a sausage recipe made from minced beef with ground mango kernels at $1.5 \%{ }^{*}$ Myoglobin pigments were determined in dayl after 24 hours from treatments. The results of $\mathrm{Mb}, \mathrm{MbO}_{2}$ and $\mathrm{MMB} \%$ were the outcome of 3 repeated measurements for each treatments. Mean values with different capital letters within a row are statistically different at $\mathrm{P}$ value less than or equal the significance level $\mathrm{P} \leq 0.05$ for $\mathrm{MbO}_{2}$ and $\mathrm{MMb}$.** no statistical significant has been found for Mb pigment.

\subsection{Myoglobin Pigments}

Fresh minced beef at day one represent $30 \% \mathrm{Mb}, 29 \% \mathrm{MbO}_{2}$ and $15 \% \mathrm{MMb}$ respectively. Changes in the type of myoglobin in beef sausages over a 12-day storage period showed significant differences $(p \leq 0.05)$ between the treatments specifically $\mathrm{MbO}_{2} \%$ and $\mathrm{MMb} \%$. At day 6, the proportion of $\mathrm{Mb}$ was almost stable in the sprayed MK of the sausages.

\subsection{TBARS and Red Color during Storage Period at $4{ }^{\circ} \mathrm{C}$}

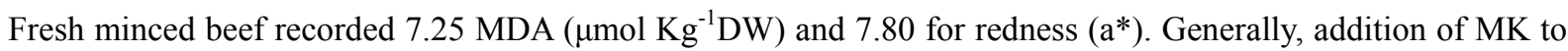
the beef sausages lowerd TBARS values compared to the controls over the 12 days of storage period. In the control (I) beef sausage TBARS values were increased significantly $(\mathrm{P} \leq 0.05)$ at day 4 and continued to increase.

There were no differences in $\mathrm{a}^{*}$ between the control and treated sausages at day one. All the treatments of beef sausages decreased their $\mathrm{a}^{*}$ values from day 1 to day 12 . There was a significant decrease $(\mathrm{P} \leq 0.05)$ in the $\mathrm{a}^{*}$ values of the control (I) sausages, specifically at day 6 . In the control sausages seems to continually decrease $a^{*}$ values to day 12 while the sausages with antioxidants, specifically those with sprayed, ground and extracts, looks to have a* up to day 12 .

Table 4. TBARS (MDA) and a* values in sausages treated with the 3 forms of MK $\left(4^{\circ} \mathrm{C}\right)$

\begin{tabular}{|c|c|c|c|c|c|c|c|c|c|c|}
\hline \multirow[t]{2}{*}{ Days } & \multicolumn{5}{|c|}{$\begin{array}{c}\text { MDA } \\
\mu \mathrm{mol} \mathrm{Kg}{ }^{-1} \mathrm{DW}\end{array}$} & \multicolumn{5}{|l|}{$\mathrm{A}^{*}$} \\
\hline & Control & BHT & Extract & Spray & Ground & Control & BHT & Extract & Spray & Ground \\
\hline $\begin{array}{l}\text { Minced } \\
\text { beef }\end{array}$ & & & $7.25 \pm 0.6$ & & & & & $7.8 \pm 0.9$ & & \\
\hline $1 * *$ & $7.75 \pm 1.2^{\mathrm{a}}$ & $6.0 \pm 1.0^{\mathrm{b}}$ & $6.0 \pm 3.7^{\mathrm{b}}$ & $6.0 \pm 0.7^{\mathrm{b}}$ & $7.0 \pm 2.2^{\mathrm{c}}$ & $7.75 \pm 2.3^{\mathrm{a}}$ & $7.68 \pm 1.4^{\mathrm{a}}$ & $7.75 \pm 1.9^{\mathrm{a}}$ & $7.75 \pm 2.3^{\mathrm{a}}$ & $8.0 \pm 1.6^{\mathrm{a}}$ \\
\hline 2 & $7.0 \pm 2.4^{\mathrm{a}}$ & $6.2 \pm 1.8^{\mathrm{b}}$ & $6.2 \pm 1.5^{b}$ & $6.1 \pm 0.9^{b}$ & $6.6 \pm 1.9^{c}$ & $6.5 \pm 1.6^{\mathrm{a}}$ & $7.5 \pm 1.8^{\mathrm{b}}$ & $7.4 \pm 1.6^{\mathrm{b}}$ & $7.5 \pm 0.9^{b}$ & $8.25 \pm 1.3^{\mathrm{c}}$ \\
\hline 4 & $7.0 \pm 0.8^{\mathrm{a}}$ & $6.2 \pm 2.1^{\mathrm{b}}$ & $6.2 \pm 2.4^{\mathrm{b}}$ & $6.1 \pm 1.1^{\mathrm{b}}$ & $7.0 \pm 1.7^{\mathrm{a}}$ & $6.0 \pm 1.0^{\mathrm{a}}$ & $6.75 \pm 0.6^{\mathrm{b}}$ & $7.1 \pm 1.2^{b}$ & $7.0 \pm 1.1^{\mathrm{b}}$ & $7.0 \pm 2.4^{b}$ \\
\hline 6 & $12.0 \pm 1.1^{\mathrm{a}}$ & $6.5 \pm 0.9^{b}$ & $6.5 \pm 1.6^{\mathrm{b}}$ & $6.4 \pm 2.0^{\mathrm{b}}$ & $9.0 \pm 1.4^{\mathrm{ab}}$ & $5.0 \pm 0.4^{\mathrm{a}}$ & $6.65 \pm 0.2^{\mathrm{b}}$ & $6.75 \pm 1.7^{\mathrm{b}}$ & $6.75 \pm 2.6^{b}$ & $6.25 \pm 0.9^{\mathrm{c}}$ \\
\hline 8 & $13.0 \pm 3.1^{\mathrm{a}}$ & $9.5 \pm 1.4^{\mathrm{b}}$ & $6.5 \pm 1.3^{\mathrm{ab}}$ & $6.1 \pm 2.3^{\mathrm{ab}}$ & $9.1 \pm 0.8^{\mathrm{b}}$ & $4.25 \pm 2.5^{\mathrm{a}}$ & $6.5 \pm 1.2^{\mathrm{b}}$ & $6.65 \pm 0.5^{b}$ & $6.75 \pm 1.8^{\mathrm{b}}$ & $5.75 \pm 1.7^{\mathrm{c}}$ \\
\hline 10 & $13.0 \pm 6.4^{\mathrm{a}}$ & $10.5 \pm 1.2^{b}$ & $5.75 \pm 1.5^{\mathrm{c}}$ & $5.5 \pm 1.2^{\mathrm{d}}$ & $10.2 \pm 1.3^{b}$ & $3.5 \pm 1.9^{\mathrm{a}}$ & $6.70 \pm 1.3^{b}$ & $6.5 \pm 2.7^{b}$ & $7.0 \pm 1.6^{\mathrm{c}}$ & $5.5 \pm 2.8^{\mathrm{ab}}$ \\
\hline 12 & $15.0 \pm 4.2^{\mathrm{a}}$ & $13.0 \pm 1.7^{b}$ & $6.25 \pm 2.4^{\mathrm{ab}}$ & $5.75 \pm 1.6^{d}$ & $12.0 \pm 0.6^{\mathrm{b}}$ & $3.0 \pm 1.1^{\mathrm{a}}$ & $7.0 \pm 2.2^{\mathrm{b}}$ & $6.5 \pm 2.1^{\mathrm{c}}$ & $7.5 \pm 1.2^{\mathrm{ab}}$ & $6.00 \pm 1.4^{\mathrm{d}}$ \\
\hline
\end{tabular}

Control: Standard sausage recipe made from minced beef with no antioxidants, BHT: a sausage recipe made from minced beef at $0.02 \%$ BHT, Extract: a sausage recipe made from minced beef and blended with MK extract at $1.5 \%$, Spray: a sausage recipe made from minced beef and sprayed with mango kernels extract at $1.5 \%$. Ground: a sausage recipe made from minced beef with ground mango kernels at $1.5 \%$, *a indicates to the degree of redness of beef sausage. **Day 1 means determinations had been done after 24 hours from treatments. (Mean values with different small letter within a row are significantly different $(\mathrm{P} \leq 0.05)$.

\subsection{Microbiological Profile of Beef Sausage With MK Extract}

Fresh minced beef and beef sausages with sprayed MK at $1.5 \%$ were only tested for microbiological investigation; TVC, E. coli, staphylococcus aureus, clostridiums, yeasts, moulds and salmonella. The microbiological investigations 
were included the period of fresh state of minced beef and day 12 at $4{ }^{\circ} \mathrm{C}$ (Table 5).

Table 5. Microbiological profile of beef sausage with MK extract

\begin{tabular}{|c|c|c|c|c|c|c|}
\hline Profile & $\begin{array}{l}\text { TVC } \\
\text { cfu g }^{-1}\end{array}$ & $\begin{array}{l}\text { E. coli } \\
\text { Cfu g }^{-1}\end{array}$ & $\begin{array}{l}\text { Clostridiums } \\
\text { cfu g }^{-1}\end{array}$ & $\begin{array}{l}\text { Staphylococci } \\
\text { cfu g }^{-1}\end{array}$ & $\begin{array}{l}\text { Yeasts \& } \\
\text { Moulds } \\
\text { cfu g }^{-1}\end{array}$ & Salmonella** \\
\hline $\begin{array}{l}\text { Fresh minced } \\
\text { beef }\end{array}$ & $\begin{array}{l}1,000,0 \\
00\end{array}$ & $>1000$ & $<10$ & $<10$ & $2.4 \times 10^{2}$ & $\mathrm{Nd}$ \\
\hline $\begin{array}{l}\text { *Beef sausage } \\
\text { sprayed MK } \\
\text { (day 12) }\end{array}$ & $\begin{array}{l}<100,0 \\
00\end{array}$ & $<5$ & $<10$ & $<10$ & $\mathrm{Nd}$ & $\mathrm{Nd}$ \\
\hline
\end{tabular}

*Sausage recipe made from minced beef and blended with mango kernels extract at $25 \mathrm{mg} / \mathrm{mL}$. nd: Nondetected cfu g ${ }^{-1}$ : colony-forming units per gram TVC: total viable count. ${ }^{* *}$ Salmonella per $10 \mathrm{~g}$ sample.

The results of TVC, E. coli, Clostridiums, Staphylococci, Yeasts \& Moulds and Salmonella in fresh minced beef represent $1,000,000,>1000,<10,<10,2.4 \times 10^{2} \mathrm{cfu} \mathrm{g}^{-1}$ and not detected respectively. While the results of beef sausage blended with MK extract at $1.5 \%$ (day 12) were $<100,000,<5,<10,<10$, nd and nd respectively. Coliforms (E. coli) were improved from minced beef and beef sausages were less than $10 \mathrm{cfu}^{-1}$. Also the concentrations of yeasts and moulds in the sprayed beef sausages were not detected at day 12. Salmonella were not detected in any of the beef samples tested.

\section{Discussion}

The current study was focused to optimize the best form that would prolong the shelf life of beef sausages. A series of analyses were done to evaluate the best form that enhances the shelf life of beef sausages at $1.5 \%$ for a period of 12 days at $4{ }^{\circ} \mathrm{C}$. For example, analysis of color, odor, and TBARS were conducted. The minced beef and beef sausage treated with sprayed MK were also examined for microbiological safety. Two controls were used $v s$ the treated beef sausage with kernels. These controls were BHT supplemented sausages as commercial synthetic at $0.02 \%$ and beef sausages without any additives.

We have already data about the antioxidative and antimicrobial effects of extract plant origin on processed meat for example, Carpenter et al. (2007) who reported an increase in redness of cooked pork patties containing the highest concentrations of grape seed extract. Also, these authors observed that this increase in meat redness was not perceived as negative by the sensory panel.

We have also data from literature about the role of MK to extend the shelf life of meat products in a state of ground or extract. (Gadallah \& Abdel Fatah, 2011; Hung, 2012; Pereira et al., 2011). As they tested the antioxidative and antibacterial effect of MK either as ground form or as an extract at different levels on the shelf life of meat products over certain days of cold storage. These studies showed extended shelf life as the antioxidative and antimicrobial effects of mango seed kernels. However, we have not yet a conclusion about the best form of MK to prolong the shelf life of beef sausages. For the first time, we have investigated the effect of spraying MK in an extract form at $1.5 \%$ over minced beef of sausage in order to testing if spraying MK may extend the shelf life of beef sausages than other forms.

Thiobarbituric acid reactive substances (TBA), analysis of color, myoglobin and odor and microbiological examination were used to assess the shelf life of the treated beef sausages.

Currently, there is a market trend to utilize from natural antioxidants as food additives because of observed safety and toxicity problems associated with synthetic antioxidants such as BHA, BHT and TBHQ (Buxiang \& Fukuhara, 1997; Jo et al., 2006). MK has been suggested as potential sources of natural antioxidants since they contain polyphenols, anthocyanin, carotenoid, vitamin C and vitamin E (Soong et al., 2004; Ajila et al., 2007). There is, however, still little data on the effects of MK on lipid oxidation associated with color and odor changes in beef sausages stored in cold environment.

Soong et al. (2004) reported that MK has potent antioxidant activity with not only phenolic compounds but also lipophilic antioxidants such as phytosterols and tocopherols that possesses strong scavenging abilities to capture free radicals and chelate metals. 
Furthermore, although BHT has often been used to prevent the harmful effects of lipid oxidation, sprayed MK was more effective than extract, ground, and BHT in the present study. This is probably due to the various kinds of antioxidants in the sprayed MK having a cloud of droplets cover the large surfaces of minced beef to make beef sausage and generally the sprayed form was extracted as having antioxidants as hydrophilic and hydrophobic forms therefore enhancing the antioxidative effects on muscle systems. Abdalla et al. (2007) also suggested that MK extracts could be used as a source of natural antioxidants therefore this study used this recommendation to test spraying extract of MK over beef sausage.

The findings in this study suggest that lipid oxidation influences the parameters of lipid oxidation of control (I) over the 12 days storage period. These findings suggest that TBARS, $\mathrm{Mb}$ and $\mathrm{MMb}$ increased whilst $\mathrm{MbO}_{2}$, odor score and $\mathrm{a}^{*}$ value decreased when lipid oxidation occurred.

The results can be attributed to the oxidation of $\mathrm{MbO}_{2}$ to $\mathrm{MMb}$ after the first 4 days of storage. A factor responsible for meat discoloration and $\mathrm{MbO}_{2}$ oxidation is lipid oxidation (Brown \& Mebine, 1969; Gray et al., 1996) which produces free radicals and aldehydes that react with $\mathrm{MbO}_{2}$ therefore speed up the accumulation of $\mathrm{MMb}$.

The sprayed MK over minced beef sausages exhibited antimicrobial effects against $E$. coli, yeasts and moulds and TVC in the beef sausages. In our study, the effect of the sprayed extract of "Zebda" mango kernels could be increased the antioxidant and antimicrobial capacity of beef sausages. As they were treated by spraying, then packed and stored at $4{ }^{\circ} \mathrm{C}$ for 12 days.

Odor is the most important parameter that affects the consumer perception of the quality of stored cold meat. We evaluate the changes in the quality of beef sausages beside changes in TBARS, color, myoglobin and microbial test in the same samples.

Sprayed MK sausage samples were more effective in maintaining the redness in beef sausages. While all sausages tended to be less red in the storage days, those with additives MK and BHT had a redder color and maintained the redness in a stable form from day 6 to the end of the storage period.

Loss in redness may be attributed to the myoglobin $(\mathrm{Mb})$ and oxymyoglobin $\left(\mathrm{MbO}_{2}\right)$ in beef products being lost by oxidation which turns the pigment to a brown color due to metmyoglobin formation. These differences may be due to the type of muscle analyzed.

The best results were obtained from sprayed MK probably extraction helped to obtain high concentration of antioxidants and reduce any unnecessary anti-nutrients. Furthermore, spraying the extract over minced beef that used in the preparation of beef sausages would help the efficiency of the antioxidants and generate droplets of extract that can be suit fat soluble antioxidants to the lipid phase and generate a potent in vitro antimicrobial of beef sausages.

The addition of MK and BHT may be changed the three forms of myoglobin pigments. This could be due to either the immediate effect of BHT and $\mathrm{MK}$ increasing $\mathrm{MbO}_{2}$ and reducing $\mathrm{Mb}$ and $\mathrm{MMb}$. These results were in agreement with (Hung, 2012).

Nevertheless, after day one, there were incompatible changes in $\mathrm{Mb}, \mathrm{MbO}_{2}$ and $\mathrm{MMb}$ of beef sausages at day 2 and 4 , respectively due to the complex changes in the formation and loss of the three myoglobin forms inter-conversion of the three forms of pigments in the presence of oxygen (Giddings, 1974; van Laack et al., 1990; Zhu \& Brewer, 1998). Also oxidation of the ferrous-species of myoglobin to the brown ferric-species $\mathrm{MMb}$ due to the prolonged exposure to air and the low oxygen pressure (Lindahl et al., 2006).

The microbiological results of beef sausage sprayed with MK indicate that coliforms $(E$. coli) were improved from minced beef and beef sausages less than $10 \mathrm{cfu} \mathrm{g}^{-1}$. Also the concentrations of yeasts and moulds in the sprayed beef sausages were not detected at day 12. Salmonellae were not detected in any of the beef samples tested. These results imply that spraying of MK has a potential antimicrobial activity against TVC in beef sausages until the day 12 .

\section{Conclusion}

Mango kernel is a good source of flavonoids ( $142 \mathrm{mg} / \mathrm{g} \mathrm{F.W.} \mathrm{GAE)} \mathrm{found} \mathrm{to} \mathrm{be} \mathrm{an} \mathrm{excellent} \mathrm{additive} \mathrm{to} \mathrm{prolong}$ shelf life of beef sausage for 12 day at $4{ }^{\circ} \mathrm{C}$. Generally, mango kernels forms, when added at $1.5 \%$ level to beef sausages provided sufficient antioxidants to extend the shelf life of beef sausages from 2 to 12 specifically in a spray form. Similarly, MK extract and ground prolonged the shelf life of beef sausages for 2 to 6 days and from 2-8 days respectively compared to control sausages (without additives). The potential effect of sprayed MK extract to extend the shelf life of beef sausages could be due to covering the large surface of minced with the tiny 
droplets of extract that inhibiting the lipid oxidation and delaying the changes in color and odor of beef sausages. Hierarchically, sprayed MK extract excelled significantly the other forms of mango kernels that mixed dried or extract with beef sausages. This study suggests the efficient antioxidative and antimicrobial properties of sprayed mango kernels extract to inhibit lipid oxidation and extend the shelf life of beef sausage.

\section{Acknowledgments}

The author thanks the following people who had an influential effect on the outcomes of this work: Department of Biochemistry, Faculty of Veterinary, Cairo University, for technical assistance in chemical analyses, Institution of Animal Research Institute, and National Research Centre Giza, Egypt, for the technical assistance in microbiology analyses.

\section{References}

Abdalla, A. E. M., Darwish, S. M., Ayad, E. H. E., \& EL-Hamahmy, R. M. (2007). Egyptian mango by-product 1. Compositional quality of mango seed kernel. Food Chemistry, 103(4), 1134-1140. http://dx.doi.org/10.1016/j.foodchem.2006.10.017

Abdel-Moemin, A. R., \& Aborya, A. O. (2014). Innovative products of coffee and tea based on dandelion (Taraxacum officinale) roots and leaves. Agricultura, 11(1), 1-10.

Ajila, C. M., Bhat, S. G., \& Rao, U. (2007a). Valuable components of raw and ripe peels from two Indian mango varieties. Food Chemistry, 102(4), 1006-1011. http://dx.doi.org/10.1016/j.jff.2012.11.017

Ajila, C. M., Naidu, K. A., Bhat, S. G., \& Rao, U. P. (2007b). Bioactive compounds and antioxidant potential of mango peel extract. Food Chemistry, 105(3), 982-988. http://dx.doi.org /10.1016/j.foodchem.2007.04.052

AOAC International. (1995). Official Methods of Analysis of AOAC International, AOAC Official Method 981.10 Crude Protein in Meat: Block Digestion Method, ISBN 0-935584-54-4. Arlington, US.

Buxiang, S., \& Fukuhara, M. (1997). Effects of co-administration of butylated hydroxytoluene, butylated hydroxyanisole and flavonoids on the activation of mutagens and drug-metabolizing enzymes in mice. Toxicology, 122, 61-72. http://dx.doi.org/10.1016/S0300-483X(97)00078-4

Carpenter, R., O'Grady, M. N., O'Callaghan, N., O'Brien, M., \& Kerry, J. P. (2007). Evaluation of the antioxidant potential of grape seed and bearberry extracts in raw and cooked pork. Journal of Meat Science, 76, 604-610. http://dx.doi.org/10.1016/j.meatsci.2007.01.021

Clydesdale, F. M. (1978). Colorimetry-methodology and applications. In T. E. Furia (Ed), Critical Reviews in Food Science and Nutrition (pp. 243-301). Boca Raton, Fla: CRC Press. http://dx.doi.org/10.1080/10408397809527252

Gadallah, M. G. E., \& Abdel, F. A. A. (2011). The antibacterial effect of mango seed kernel powder in minced beef during refrigerated storage. World Journal of Dairy \& Food Sciences, 6(2), 219-228.

Hung, M. L. E. (2012). Antioxidative effects of mango wastes on shelf life of pork products, Ph.D. Thesis, p.V Lincoln University.

JO, S. C., Nam, K. C., Min, B. R., Ahn, D. U., Cho, S. H., Park, W. P., \& Lee, S. C. (2006). Antioxidant activity of Prunus mume extract in cooked chicken breast meat. International Journal of Food Science and Technology, 41, 15-19. http://dx.doi.org/10.1111/j.1365-2621.2006.01234.x

Kader, A. A. (2008). National Mango Board: Mango quality attributes and grade standards-A review of available information and identification of future research. Retrieved February 25, from http://www.mango.org/mango/sites/default/files/download/mango_grade_standards_review_full_report.pdf

Kittiphoom, S. (2012). Utilization of Mango seed. International Food Research Journal, 19(4), 1325-1335.

Ladikos, D., \& Lougovois, V. (1990). Lipid oxidation in muscle foods: A review. Food Chemistry, 35(4), 295-314. http://dx.doi.org/10.1016/0308-8146(90)90019-Z

Lee, B. J., Hendricks, D. G., \& Cornforth, D. P. (1998). Antioxidant effects of carnosine and phytic acid in a model beef system. J Food Sci, 63, Journal of Meat Science, 51, 245-253. http://dx.doi.org/10.1111/j.1365-2621.1998.tb15750.x

Madhar, A., \& Pushpalatha, P. B. (2002). Quality up gradation of jellies prepared using pectin extracted from fruit wastes. Journal of Tropical \& Agriculture, 40, 31-34. 
Maraschiello, C., Sarraga, C., \& Garcia, R. J. A. (1999). Glutathione peroxidase activity, TBARS, and $\alpha$-Tocopherol in meat from chickens fed different diets. Journal of Agriculture \& Food Chemistry, 47(3), 867-872. http://dx.doi.org/10.1021/j9980824o

Oboh, G., \& Rocha J. B. T. (2007). Distribution and Antioxidant Activity of Polyphenols in Ripe and Unripe Tree Pepper (Capsicum pubescens). Journal of Food Biochemistry, 31(4), 456-473. http://dx.doi.org/10.1111/j.1745-4514.2007.00123.x

Pereira, A. L., Fernandes V .T., Teixeira, M. C., Fontoura, O. P., Fernandes, R. C., ... Zapata, J. F. F. (2011). Antioxidant effect of mango seed extract and butylated hydroxytoluene in bologna-type mortadella during $\begin{array}{llll}\text { storage. Cienc. Tecnol. } & \text { Aliment., } & \text { Campinas, } & 31(1),\end{array}$ http://dx.doi.org/10.1590/S0101-20612011000100019

Raharjo, S., \& Sofos J. N. (1993). Methodology for measuring malonaldehyde as a product of lipid peroxidation in muscle tissues: A review. Journal of Meat Science, 35(2), 145-169. http://dx.doi.org/10.1016/0309-1740(93)90046-K

Rao, K. L. (2006). Agro-industrial parks experience from India. Agriculturral and food Engineering Working Document. Food and Agriculture Organization of the United Nations.

Singleton, V. L., \& Rossi, J. A. (1965). Colorimetry of total phenolics with phosphomolybdic-phosphotungstic acid reagents. American Journal of Enology \& Viticulture, 16, 144-158.

Soong, Y. Y., \& Barlow, P. J. (2004). Antioxidant activity and phenolic content of selected fruit seeds. Food Chemistry, 88 (3), 411-417. http://dx.doi.org/10.1016/j.foodchem.2004.02.003

Soong, Y. Y., Barlow, P. J., \& Perera, C. O. (2004). A cocktail of phytonutrients: identification of polyphenols, phytosterols and tocopherols from mango (Mangifera indica L.) seed kernel. In IFT annual meeting. July 12-16. Las Vegas, U.S.

Vasavada, M. N., \& Cornforth, D. P. (2006). Evaluation of antioxidant effects of raisin paste in cooked minced beef, pork, and chicken. Journal of Food Science, 71(4), C242-C246. http://dx.doi.org/10.1111/j.1365-2621.2005.tb07168.x

Vega-Vega, V. (2011). Enriquecimiento de la Capacidad Anti- oxidante y. Protección Antimicrobiana del Mango Fresco Cortado Aplicando Compuestos Fenólicos de sus Sub- productos,” MS.c. Thesis, Centro de Investigación en Ali- mentación y Desarrollo, A.C, Hermosillo, Sonora, Mexico.

Vega-Vega, V., Silva-Espinoza, B. A., Cruz-Valenzuela, M. R., Bernal-Mercado, A. T., González-Aguilar, G. A., Vargas-Arispuro, I., ... Ayala-Zavala, J. F. (2013). Antioxidant enrichment and antimicrobial protection of fresh-cut mango applying bioactive extracts from their seeds by-products. Food and Nutrition Sciences, 4, 197-203. http://dx.doi.org/10.4236/fns.2013.48A024

\section{Copyrights}

Copyright for this article is retained by the author(s), with first publication rights granted to the journal.

This is an open-access article distributed under the terms and conditions of the Creative Commons Attribution license (http://creativecommons.org/licenses/by/3.0/). 